\title{
Personalizing the safe, appropriate
} and effective concentration(s) of ozone for a non-diabetic individual and four type Il diabetic patients in autohemotherapy through blood hemoglobin analysis

\author{
Fouad Mehraban ${ }^{1}$, Arefeh Seyedarabi ${ }^{\text {* }^{*}}$, Shahin Ahmadian ${ }^{1}$, Vahid Mirzaaghaei
} and Ali Akbar Moosavi-Movahedi ${ }^{1}$

\begin{abstract}
Background: Diabetes is a chronic disease associated with many problems and high costs. In recent decades, a lot of research has been carried out in order to improve methods of treatment of diabetic patients. One of the currently used complementary therapies for diabetes is ozone therapy or autohemotherapy. The beneficial effects of ozone has been proven in many diseases such as diabetes, but the critical issue is the determination of the safe and effective concentration of ozone reacting with blood and in particular hemoglobin.

Methods: A number of spectroscopic techniques including intrinsic fluorescence, circular dichroism and UV-VIS spectroscopies were used as well as SDS-PAGE, Native-PAGE and dynamic light scattering to analyze the effect of ozonation on hemoglobin of a non-diabetic individual and four diabetic patients in order to find the appropriate concentration(s) of ozone for personalized autohemotherapy.

Results: In this study, we determined the personalized concentration(s) for a safe and effective ozonation of a nondiabetic individual and four diabetic type II patients, based on blood hemoglobin analysis.

Conclusions: A number of techniques were used to determine the personalized ozone concentration(s) for a safe and effective autohemotherapy based on blood hemoglobin analysis. SDS-PAGE and dynamic light scattering were identified as the two main techniques needed for personalizing the ozone concentration(s) for each individual as otherwise hemoglobin in blood can oligomerise and cause serious damage if the inappropriate ozone concentration is used.
\end{abstract}

Keywords: Autohemotherapy, Antioxidants, Diabetes, Personalized ozone therapy, Whole blood hemoglobin

\footnotetext{
*Correspondence: a.seyedarabi@ut.ac.ir

${ }^{1}$ Institute of Biochemistry and Biophysics, University of Tehran, Tehran,

Iran

Full list of author information is available at the end of the article
} 


\section{Background}

Diabetes is a metabolic disease characterized by impaired carbohydrate metabolism, inappropriate insulin production or consumption, leading to glycosuria and hyperglycemia [1]. The global prevalence of diabetes is increasing substantially. In total, since 2011, 366 million people have been diagnosed with diabetes, with type II diabetes accounting for almost $90 \%$ of all cases [2]. Type II diabetes together with type I diabetes or insulin-dependent diabetes are amongst the toughest conditions in terms of their social and economic pressures and the suffering caused. In developed countries, the number of diabetic patients is steadily rising and the rate of disability and mortality are also increasingly seen $[3,4]$. In patients with type II diabetes, which is characterized by the inability of tissues to detect insulin-sensitivity, the process of gluconeogenesis is increased in the liver where glucose uptake and its conversion in insulin-sensitive tissues are severely impaired. To eliminate these disorders, the release of insulin by beta cells increases and leads to type II diabetes, which is characterized by high levels of plasma glucose and the presence of hyperinsulinemia [5].

There is a lot of clinical evidence that has shown the increase in the production of reactive oxygen species (ROS) in both types of diabetes [6]. There is also a direct relationship between the presence of oxidative stress and the defective uptake of glucose. Antioxidant depletion associated with a reduction in the uptake of glucose in patients with type II diabetes has been reported. The imbalance in the level of active oxygen species and antioxidants plays an important role in insulin resistance, and other studies have shown that there is a close relationship between oxidative stress and insulin sensitivity. Therefore, it seems that increasing the antioxidant capacity can overcome insulin resistance [5].

Ozone is one of the most reactive gases and the third most potent oxidant after fluorine and persulfate [7] and ozone therapy has been recorded amongst the biooxidative therapies, which has been used and studied for its use as a disinfectant and for the treatment of different diseases including diabetes [8]. In the phenomenon of adaptation to chronic oxidative stress [8], which is also evaluated as oxidative pre-conditioning [9] or as hormosis $[10,11]$, it has been determined that repetitive and calculated treatment methods such as ozone therapy with the appropriate concentration and manner [12] can have a stimulated effect at concentrations lower than the inhibitory and toxic amounts [11] triggering the synthesis of oxidative stress proteins such as HO-1 [13]. Indeed, the therapeutic efficacy of ozone therapy may also be partly due to the controlled and moderate oxidative stress produced by the reaction of ozone with several biological components [11].
It has been reported that ozone therapy, through the mentioned mechanism, returns glucose levels to normal and subsequently returns the concentrations of organic peroxides to its original state and reduces hyperglycemia in patients with type II diabetes and exerts antidiabetic effects [5]. Ozone can maintain the content of glycogen, reduce the formation of lactate and uric acid, and also stimulate or maintain endogenous antioxidant systems and block the xanthine-oxidase pathway, which produces ROS, through the process of oxidative pre-conditioning and controlling the damage caused from oxidative stress by $\mathrm{CCl}_{4}$ [14-16]. Endogenous oxidative stress has a long half-life and it is different from temporary, precise and regulated oxidative stress caused by exposure of ex vivo blood of patients to oxygen and ozone gas mixture. Ozone therapy which can create this type of gentle, precise and temporary oxidative stress may reduce chronic oxidative stress and possibly the complications of diabetes [1]. Indeed, according to recent studies on the biological activity of ozone, it has been proven that low and carefully adjusted ozone concentrations unexpectedly induce an adaptive response that can reduce the endogenous oxidative stress $[8,17,18]$.

One of the most common and effective methods of ozone therapy for patients is autohemotherapy $\left(\mathrm{O}_{3}\right.$-AHT $)$, which involves the exposure of a certain amount of blood from the patient, along with sodium citrate as an anticoagulant, with an equal volume of oxygen (95\%) and ozone (5\%) gas mixtures, at a specific concentration per ml of blood $[12,19]$.

Ozone in the aqueous environment, which is able to quickly dissolve, gives its energy to hematic components [20], such as hemoglobin $(\mathrm{Hb})$, the most heme-containing protein in the blood circulation. Therefore, the effects of ozone on $\mathrm{Hb}$ is widely investigated [21].

The body can deal with oxidative stress via the production of endogenous or exogenous antioxidants. Antioxidants play their role by neutralizing excess free radicals and protecting cells against toxic effects and helping prevent the prevalence of disease [22]. Total antioxidant capacity (TAC) values vary in non-diabetic individuals and diabetic patients [23]. Plasma TAC measurements are considered as an important step in explaining the relationship between antioxidant status and other diseases [24].

In this study, we investigated for the first time, the effect of various concentrations of ozone on human $\mathrm{Hb}$ in the whole blood of a non-diabetic individual and four diabetic patients (with type II diabetes), in order to place emphasis on a personalized method for the identification of a safe, appropriate and effective concentration(s) of ozone for treatment of diabetic patients in $\mathrm{O}_{3}$-AHT. This study involved the use of spectroscopic studies 
such as the intrinsic fluorescence, circular dichroism (CD) and UV-VIS spectroscopies, in order to examine the changes in the secondary and tertiary structure of $\mathrm{Hb}$ and its heme group and aromatic residues, as well as Native-PAGE and in particular SDS-PAGE, in the presence and absence of dithiothreitol (DTT) (as a reducing agent), and dynamic light scattering (DLS) to analyze the oligomerization and polydispersity of $\mathrm{Hb}$ upon exposure to varying concentrations of ozone.

\section{Methods}

\section{Ozone generation}

Ozone was produced from medical-grade oxygen by an electrical corona arc discharge by an $\mathrm{O}_{3}$ generator (Gardina, Iran), which controls the amount of gas flow rate and ozone concentration using a photometry, periodically checked by the iodometric titration in accordance with the rules established by the international ozone association [25]. Blood ozonation should only be done with medical oxygen and not the filtered air which contains $78 \%$ nitrogen resulting in the unwanted formation of nitrogen oxides. Single-use silicon treated polypropylene syringes (ozone resistant) were used throughout the reaction time to ensure the stability of the ozone concentration and to prevent its leakage or contamination.

\section{Collection, ozonation and purification of $\mathrm{Hb}$}

$\mathrm{Hb}$ in whole blood samples of the non-diabetic individual and four diabetic patients were ozonated with different concentrations of ozone at 15,35 and $55 \mu \mathrm{g} / \mathrm{ml}$, purified and then dialyzed by the method used in our previous study [26].

\section{Gas delivery and whole blood sample treatments}

In our experiments, a single concentration of ozone gas mixture (concentration per volume, $\mu \mathrm{g} / \mathrm{ml}$ ) composed of oxygen (96-99\%) and ozone (1-4\%) with flow rate of $0.8 \mathrm{lit} / \mathrm{min}$ was used. The final pressure of the gas was maintained at a normal atmospheric pressure [27]. In our previous study, we reported the amount of ozone used in terms of 'ppm' and 'dose' [26]. However, in this study we are using ' $\mu \mathrm{g} / \mathrm{ml}$ ' and 'concentration', in place of those terms, as a more accurate measurement of ozone gas. The various ozone concentrations in major $\mathrm{O}_{3}$-AHT used for treatment of diabetic patients are 15,35 and $50 \mu \mathrm{g} / \mathrm{ml}$, which are also effective in peripheral arterial disease [28], with the best time duration for the effective mixing with blood being $5 \mathrm{~min}$ [19]. This time duration is needed for blood (which is viscous) to achieve complete and homogeneous equilibrium with ozone gas [29].

In this study, whole blood samples were exposed to ozone gas at 15,35 and $55 \mu \mathrm{g} / \mathrm{ml}$ of ozone for $5 \mathrm{~min}$ at a 1:1 volumetric ratio, followed by $\mathrm{Hb}$ purification [27].
$55 \mu \mathrm{g} / \mathrm{ml}$ was chosen instead of the reported $50 \mu \mathrm{g} / \mathrm{ml}$ in order to keep consistency in the increased ozone concentration levels used in this study. The control blood samples were not exposed to ozone.

\section{Fluorescence spectroscopy}

The fluorescence spectra were examined with the same apparatus and method as described in our previous study [26]. Emission spectra were measured between 300 and $400 \mathrm{~nm}$. The excitation wavelength was at $280 \mathrm{~nm}$.

\section{CD measurements}

Measurements of the CD spectra were carried out using an AVIV 215 spectropolarimeter (Aviv Associates, Lakewood, NJ, USA). All CD measurements were carried out as in our previous study [26]. The results were plotted as ellipticity (in deg. $\mathrm{cm}^{2} \mathrm{dmol}^{-1}$ ) versus wavelength in nanometers.

\section{UV-VIS absorption spectroscopy}

The same parameters as in our previous study were used to measure the UV-VIS spectra [26]. The absorbance scan spectra were measured using a UV-visible spectrophotometer (Varian, Carry 100 Bio, Australia) at an absorbance of $280 \mathrm{~nm}$ and reported in the range of 200-700 nm.

\section{SDS-PAGE and Native-PAGE}

In SDS-PAGE and Native-PAGE analyses, all conditions were the same as in our previous study and $18 \%$ gels were used [26]. Molecular weights of bands in the Hb samples were estimated by comparison with a protein marker (SMOBiO, Taiwan).

\section{Dynamic light scattering}

DLS measurements of $\mathrm{Hb}$ from the non-diabetic individual and that of the four diabetic patients were obtained using the same method as reported in our previous study [26]. The refractive index of the material (protein) and the absorption were set to 1.59 and 0.01 , respectively. The following parameters were used: the dispersant viscosity was $0.8872 \mathrm{cP}$ and the refractive index was 1.330 .

\section{Measurement of plasma TAC}

The TAC values derived from blood plasma of the nondiabetic individual and that of the four diabetic patients prior to ozone therapy were measured using the ZellBio $\mathrm{GmbH}$ kit (product of Germany) and expressed in $\mathrm{mM}$ [30].

\section{Statistical analysis}

The TAC results were averages of three measurements from blood plasma of each individual and reported as 
mean \pm SD by the Friedman test (a non-parametric test) and presented using the SPSS software, version 18.

\section{Results}

\section{Non-diabetic and type II diabetic patients}

Table 1 provides information about the non-diabetic individual and the four diabetic patients (including duration of disease), the TAC measurements from each individual's blood plasma (measured three times and averaged) and the purified $\mathrm{Hb}$ concentration of each sample after ozonation based on the absorbance reading at $280 \mathrm{~nm}$ (which is dependent on the presence or exposure of aromatic ring containing residues, in particular tryptophan and tyrosine). In this study, $\mathrm{Hb}$ from whole blood of a non-diabetic individual and four patients diagnosed with type II diabetes were analysed, in order to determine the safe and effective concentration(s) of ozone to be used for each individual in $\mathrm{O}_{3}$-AHT.

Looking at the results of $\mathrm{Hb}$ concentrations based on absorbance reading at $280 \mathrm{~nm}$ after ozonation, there seemed to be an indication that the $\mathrm{Hb}$ concentrations varied amongst the samples. This could be related to structural changes caused by ozonation such that the aromatic residues, which have absorbance at $280 \mathrm{~nm}$, were exposed differently for detection.

In the non-diabetic individual $\mathrm{A}$, the concentration of $\mathrm{Hb}$ in each of the three ozone treated concentrations compared to the non-ozonated $\mathrm{Hb}$ sample from the same individual had increased. The maximum $\mathrm{Hb}$ concentration was measured for $\mathrm{Hb}$ ozonated with $15 \mu \mathrm{g} /$ $\mathrm{ml}$ ozone. In patient $\mathrm{B}$, the highest concentration of $\mathrm{Hb}$ was measured for $\mathrm{Hb}$ ozonated with $35 \mu \mathrm{g} / \mathrm{ml}$ ozone. In patient $\mathrm{C}$, the highest concentration of $\mathrm{Hb}$ was in the presence of ozone at $15 \mu \mathrm{g} / \mathrm{ml}$. In patient $\mathrm{D}$, the highest concentration of $\mathrm{Hb}$ was in the presence of ozone at $55 \mu \mathrm{g} / \mathrm{ml}$ and in patient $\mathrm{E}$ the highest concentration was for the non-ozonated $\mathrm{Hb}$ sample. These observations will be better explained with other techniques used in this study.

\section{Ozonation of $\mathrm{Hb}$}

In this study, whole blood $\mathrm{Hb}$ was purified from a nondiabetic individual and four diabetic patients after exposure to various concentrations of ozone $(15,35$ and $55 \mu \mathrm{g} / \mathrm{ml}$ ) for $5 \mathrm{~min}$. In all cases, a slight change in blood colour from dark red in control samples to slightly bright red in ozonated samples at different concentrations were observed (Fig. 1). This indicated that ozonation affected the colour of the whole blood $\mathrm{Hb}$ slightly, but nowhere close to that observed in our previous study where the absence of antioxidants and the direct continuous bubbling of ozone in purified $\mathrm{Hb}$ samples resulted in eye catching colour changes [26], as opposed to whole blood $\mathrm{Hb}$ samples in this study, which are in the presence of antioxidants (with TAC values given in Table 1) and exposed to ozone gas in a 1:1 volumetric ratio in a syringe.

\section{Fluorescence analysis}

Fluorescence is used to evaluate changes in the tertiary structure of proteins such as $\mathrm{Hb}$ [31], which are characterized by their own intrinsic inherent fluorophores

Table 1 General information for the non-diabetic individual A and the four diabetic patients B-E

\begin{tabular}{|c|c|c|c|c|c|}
\hline Samples & Age & Gender & $\begin{array}{l}\mathrm{Hb} \text { concentration }(\mathrm{mg} / \mathrm{ml}) \text { based } \\
\text { on absorbance reading at } 280 \mathrm{~nm} \text { post } \\
\text { ozonation and dialysis }\end{array}$ & $\mathrm{TAC}(\mathrm{mM})$ & $\begin{array}{l}\text { Duration of disease } \\
\text { (medication taken) }\end{array}$ \\
\hline Individual A & 46 & Male & $\begin{array}{l}\text { Non- } \mathrm{O}_{3}: 100.70 \\
15 \mu \mathrm{g} / \mathrm{ml} \mathrm{O}_{3}: 136.48 \\
35 \mu \mathrm{g} / \mathrm{ml} \mathrm{O}_{3}: 110.01 \\
55 \mu \mathrm{g} / \mathrm{ml} \mathrm{O}_{3}: 111.48\end{array}$ & $0.274 \pm 0.009$ & - \\
\hline Patient B & 56 & Female & $\begin{array}{l}\text { Non- } \mathrm{O}_{3}: 86.63 \\
15 \mu \mathrm{g} / \mathrm{ml} \mathrm{O}_{3}: 79.61 \\
35 \mu \mathrm{g} / \mathrm{ml} \mathrm{O}_{3}: 103.14 \\
55 \mu \mathrm{g} / \mathrm{ml} \mathrm{O}_{3}: 75.38\end{array}$ & $0.207 \pm 0.006$ & $\begin{array}{l}18 \text { years } \\
\text { (Metformin) }\end{array}$ \\
\hline Patient C & 66 & Male & $\begin{array}{l}\text { Non- } \mathrm{O}_{3}: 66.12 \\
15 \mu \mathrm{g} / \mathrm{ml} \mathrm{O}_{3}: 94.41 \\
35 \mu \mathrm{g} / \mathrm{ml} \mathrm{O}_{3}: 80.59 \\
55 \mu \mathrm{g} / \mathrm{ml} \mathrm{O}_{3}: 70.15\end{array}$ & $0.341 \pm 0.015$ & $\begin{array}{l}20 \text { years } \\
\text { (Insulin) }\end{array}$ \\
\hline Patient D & 60 & Male & $\begin{array}{l}\mathrm{Non}^{-\mathrm{O}_{3}}: 48.41 \\
15 \mu \mathrm{g} / \mathrm{ml} \mathrm{O}_{3}: 63.92 \\
35 \mu \mathrm{g} / \mathrm{ml} \mathrm{O}_{3}: 74.52 \\
55 \mu \mathrm{g} / \mathrm{ml} \mathrm{O}_{3}: 86.88\end{array}$ & $0.370 \pm 0.013$ & $\begin{array}{l}1 \text { year } \\
\text { (Metformin) }\end{array}$ \\
\hline Patient E & 41 & Female & $\begin{array}{l}\text { Non-O }{ }_{3}: 62.80 \\
15 \mu \mathrm{g} / \mathrm{ml} \mathrm{O}_{3}: 59.38 \\
35 \mu \mathrm{g} / \mathrm{ml} \mathrm{O}_{3}: 57.40 \\
55 \mu \mathrm{g} / \mathrm{ml} \mathrm{O}_{3}: 55.65\end{array}$ & $0.271 \pm 0.029$ & $\begin{array}{l}5 \text { years } \\
\text { (Insulin) }\end{array}$ \\
\hline
\end{tabular}




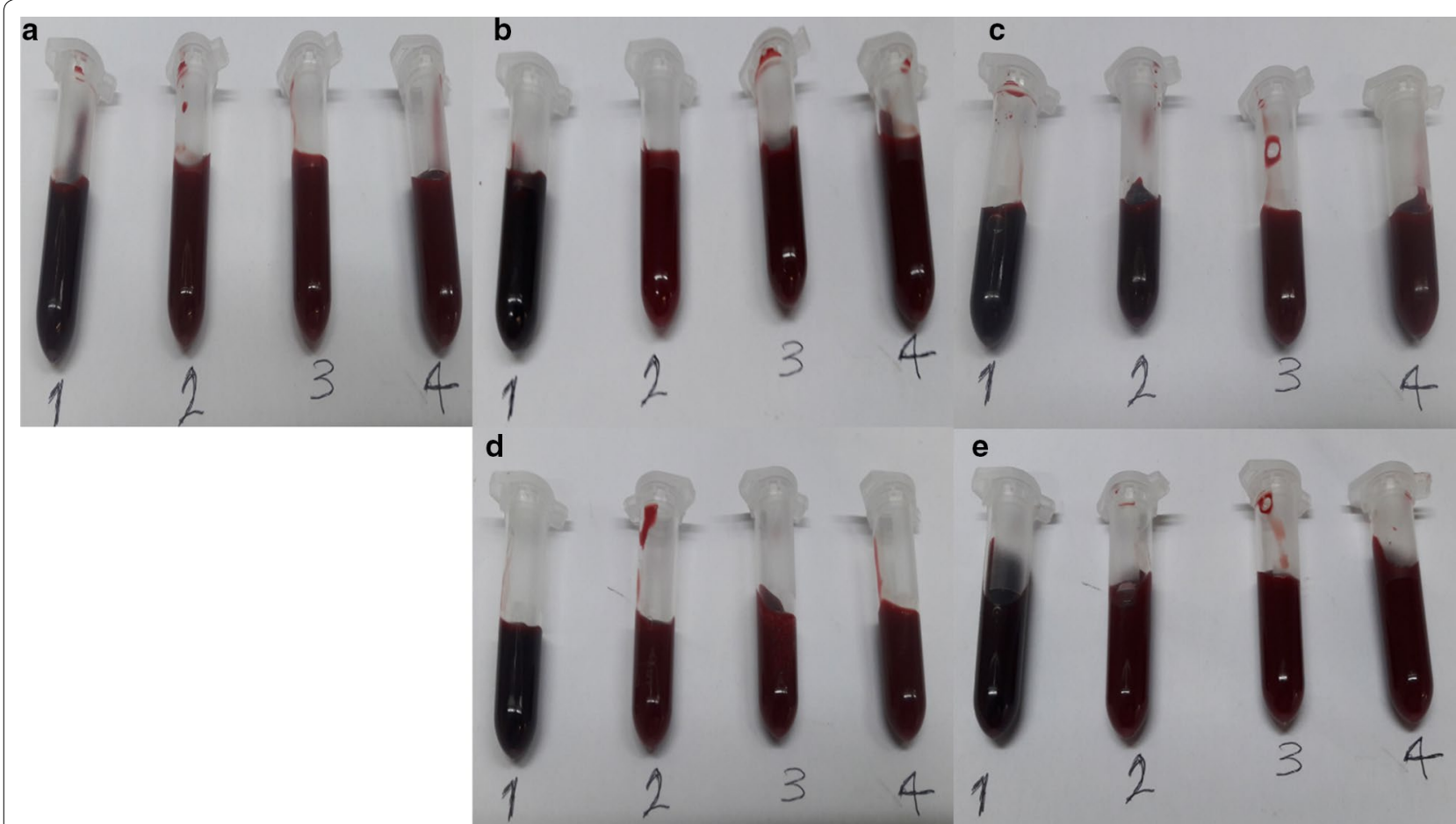

Fig. 1 Visual colour representation of oxy-Hb from five human blood samples. $\mathbf{a} \mathrm{Hb}$ of the non-diabetic individual A. $\mathbf{b}-\mathbf{e} \mathrm{Hb}$ of the diabetic patients $B$ to $\mathrm{E}$, respectively. In all cases, sample number 1 refers to non-ozonated $\mathrm{Hb}$, while samples number 2,3 and 4 are related to ozone treated $\mathrm{Hb}$ with 15,35 and $55 \mu \mathrm{g} / \mathrm{ml}$ of ozone, respectively, for $5 \mathrm{~min}$

including that of tyrosines, phenylalanines and predominantly tryptophans. There is a $\beta$-Trp37 located in the $\alpha 1 \beta 2$ interface which seems to play a major role in the intrinsic fluorescence of $\mathrm{Hb}$ [32]. In the non-diabetic individual A, no change in intensity of fluorescence peak was observed for $\mathrm{Hb}$ exposed to different concentrations of ozone compared to its control non-ozonated Hb sample, consistent with our previous study [26].

In the diabetic patient $\mathrm{B}$, the ozone concentration of $35 \mu \mathrm{g} / \mathrm{ml}$ had reduced the $\mathrm{Hb}$ peak intensity while ozone concentrations of $15 \mu \mathrm{g} / \mathrm{ml}$ and $55 \mu \mathrm{g} / \mathrm{ml}$ had increased the intensity of the $\mathrm{Hb}$ peak. In the diabetic patient $\mathrm{C}$, the ozone concentration of $15 \mu \mathrm{g} / \mathrm{ml}$ had reduced the $\mathrm{Hb}$ peak intensity slightly. In the diabetic patient $\mathrm{D}$, ozone concentrations of $55 \mu \mathrm{g} / \mathrm{ml}$ followed by $35 \mu \mathrm{g} / \mathrm{ml}$ had reduced the peak intensities, while ozone concentration of $15 \mu \mathrm{g} / \mathrm{ml}$ was able to raise the peak intensity close to that seen for the non-ozonated $\mathrm{Hb}$ sample. In the diabetic patient $E$, there was no major change in peak intensity for the varying ozone concentrations. What is interesting is the direct relationship between the $\mathrm{Hb}$ concentrations as listed in Table 1 and the intrinsic fluorescent peaks seen in Fig. 2. For example, the trend for the highest to lowest concentrations (based on absorbance readings at $280 \mathrm{~nm}$ ) of $\mathrm{Hb}$ for patient $\mathrm{B}$ is related to $\mathrm{Hb}$ ozonated at $35 \mu \mathrm{g} /$ $\mathrm{ml}$, followed by non-ozonated, then $15 \mu \mathrm{g} / \mathrm{ml}$ and finally $55 \mu \mathrm{g} / \mathrm{ml}$ ozone. This trend is also consistent in Fig. $2 \mathrm{~b}$, where the lowest peak with the highest intrinsically exposed $\mathrm{Hb}$ structure is related to $\mathrm{Hb}$ treated with $35 \mu \mathrm{g} /$ $\mathrm{ml}$ ozone. This is much more clearly apparent for patient $\mathrm{D}$ at $55 \mu \mathrm{g} / \mathrm{ml}$. The reason for this could be that ozone concentrations of 35 and $55 \mu \mathrm{g} / \mathrm{ml}$ used for Hb samples of patients $B$ and $D$, respectively, caused a change and polarization in the surrounding environment of the fluorophores and that of $\beta$-Trp37 in $\mathrm{Hb}$, in particular, resulting in lower fluorescence peak intensity and a more open structure compared to the non-ozonated and other ozone treated $\mathrm{Hb}$ samples for these patients.

\section{CD measurements Far-UV CD}

$C D$ measurements are used to study changes in the structure of proteins [31]. In far-UV CD the alpha helical structure of a protein is detected through two highly negative peaks at $209 \mathrm{~nm}$ and $222 \mathrm{~nm}$, which are related to the $\pi-\pi^{*}$ transition in $\alpha$-helix and $n-\pi^{*}$ transition in both $\alpha$-helix and random coil conformations, respectively $[33,34]$. As you can see in Fig. 3 , in the nondiabetic individual $\mathrm{A}$, we have the most negative peaks with highest alpha helix content for the non-ozonated 

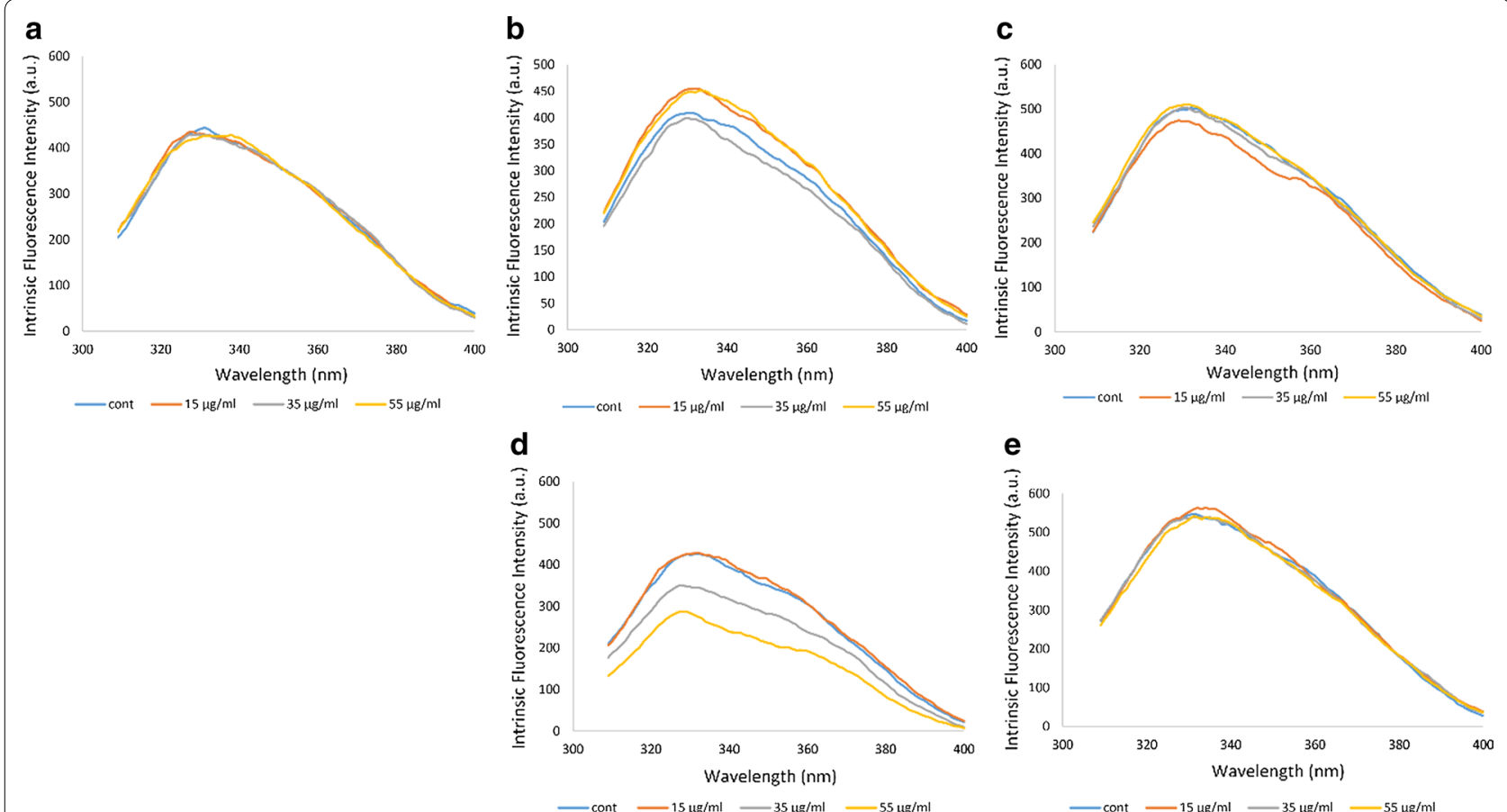

Fig. 2 Evaluating the intrinsic fluorescence spectral changes of oxy-Hb from five human blood samples. The fluorescence spectra were measured after excitation at $280 \mathrm{~nm}$. a Fluorescence spectra of oxy-Hb for the non-diabetic individual A. b-e Fluorescence spectra of oxy-Hb for the diabetic patients $B$ to E, respectively
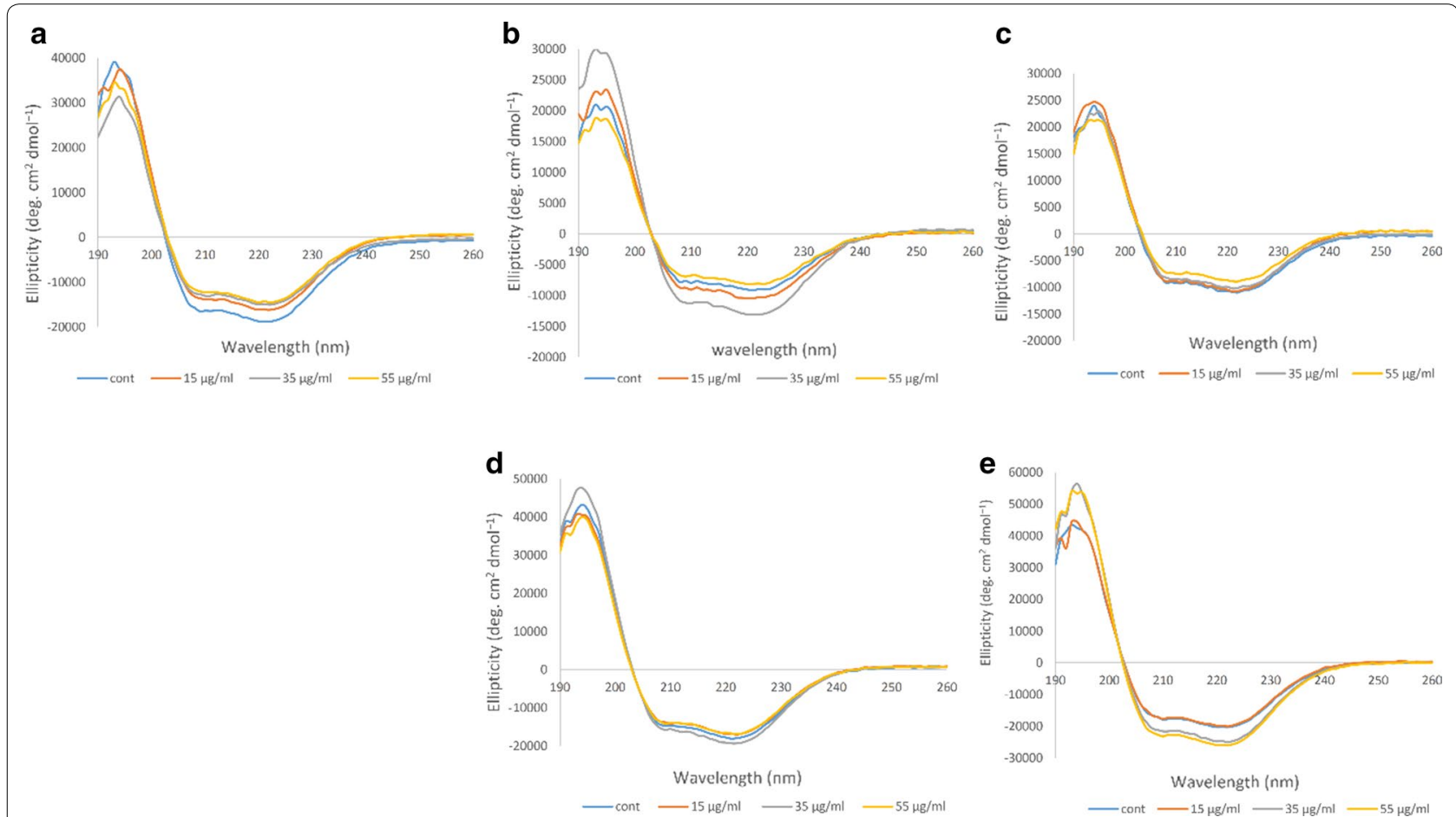

Fig. 3 Far-UV CD spectral changes of ozonated whole blood oxy-Hb from five human samples. a Far-UV spectra of oxy-Hb for the non-diabetic individual A. b-e Far-UV spectra of oxy-Hb for the diabetic patients B to E, respectively 
$\mathrm{Hb}$ sample, which decreases in intensity when treated with $15 \mu \mathrm{g} / \mathrm{ml}$ ozone. In the diabetic patient $\mathrm{B}$, minor changes were observed for $\mathrm{Hb}$ samples treated with $15 \mu \mathrm{g} / \mathrm{ml}$ and $55 \mu \mathrm{g} / \mathrm{ml}$ ozone compared to the non-ozonated $\mathrm{Hb}$ sample, while ozone concentration of $35 \mu \mathrm{g} / \mathrm{ml}$ resulted in pronounced increase in peak intensities and an increase in the alpha helix content. In the diabetic patient $C$, the intensity of both peaks was not significantly different between the non-ozonated and ozone treated $\mathrm{Hb}$ samples. In the diabetic patient $\mathrm{D}$, changes were also negligible between the non-ozonated and ozone treated $\mathrm{Hb}$ samples. As for the diabetic patient $\mathrm{E}$, ozone concentrations of $55 \mu \mathrm{g} /$ $\mathrm{ml}$ followed by $35 \mu \mathrm{g} / \mathrm{ml}$ showed a noticeable increase in peak intensities indicative of increased alpha helix content.

\section{Near-UV CD}

Near-UV is also sensitive to changes in the aromatic residues, which reflects the tertiary structure of proteins such as $\mathrm{Hb}$, through a highly positive band at a wavelength of $260 \mathrm{~nm}[33,34]$. Figure 4 shows the results related to the $\mathrm{Hb}$ of the non-diabetic individual and the four diabetic patients. In the $\mathrm{Hb}$ samples of the non-diabetic individual A, the different concentrations of ozone had no major effect on the near-UV band and only ozonation at $35 \mu \mathrm{g} /$ $\mathrm{ml}$ caused a slight increase in the intensity of the band. In the $\mathrm{Hb}$ samples of the diabetic patient $\mathrm{B}$, changes in the Near-UV band was more evident, such that ozonation at $35 \mu \mathrm{g} / \mathrm{ml}$ caused a great reduction in intensity of the band while ozonation at $55 \mu \mathrm{g} / \mathrm{ml}$ and especially $15 \mu \mathrm{g} /$ $\mathrm{ml}$ greatly increased the intensity of the band compared to the non-ozonated $\mathrm{Hb}$ sample. In the diabetic patient $\mathrm{C}$, ozone concentration of $35 \mu \mathrm{g} / \mathrm{ml}$ caused the Near-UV band to be close to the control non-ozonated Hb sample, while ozonation at 15 and $55 \mu \mathrm{g} / \mathrm{ml}$ reduced the intensity of the band. As for the diabetic patient $\mathrm{D}$, the band intensity was overall high and only ozonation at $35 \mu \mathrm{g} / \mathrm{ml}$ resulted in reduction in the intensity of the band.

In the diabetic patient $\mathrm{E}$, ozone concentrations of $15 \mu \mathrm{g} / \mathrm{ml}$ and $55 \mu \mathrm{g} / \mathrm{ml}$ did not show any significant difference and appeared to be similar to the control nonozonated $\mathrm{Hb}$ sample from this patient, while ozone concentration of $35 \mu \mathrm{g} / \mathrm{ml}$ showed a relatively noticeable increase in the intensity of the band at $260 \mathrm{~nm}$.

\section{Soret-UV CD}

The Soret-UV or B-band shows changes in the heme group, which includes binding of the heme group to the globin as well as oxygen. Indeed, when the heme group is attached to the globin, the signal of the Soret region, which is characterized by a highly positive band at
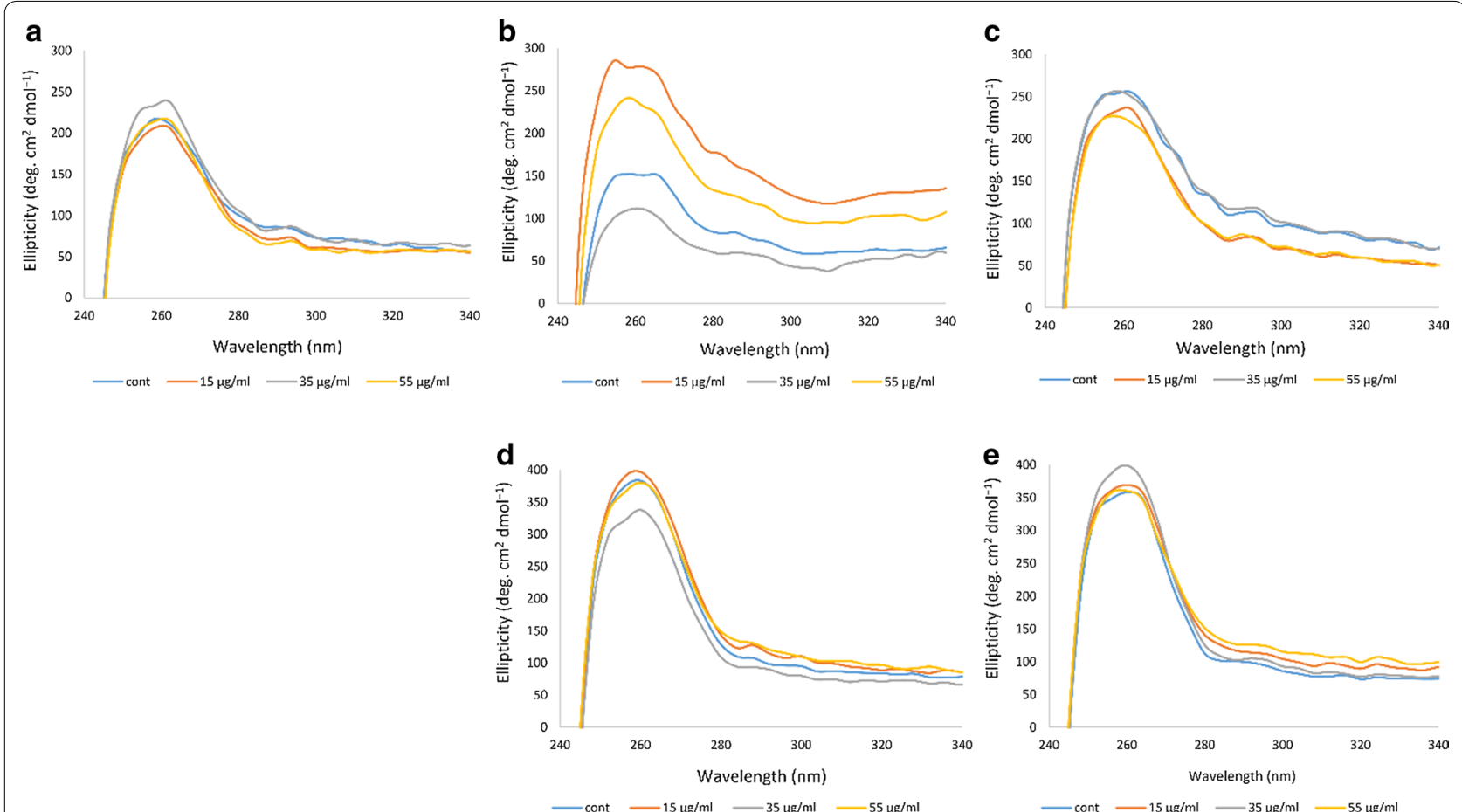

Fig. 4 Near-UV CD spectral changes of ozonated whole blood oxy-Hb from five human samples. a Near-UV spectra of oxy-Hb for the non-diabetic individual A. b-e Near-UV spectra of oxy-Hb for the diabetic patients B to E, respectively 
$410 \mathrm{~nm}$, is recognizable [31]. Similar to the results seen in the Near-UV studies, Fig. 5 shows that in the Hb samples of the diabetic patient B, changes in the Soret band of $\mathrm{Hb}$ exposed to various concentrations of ozone were more pronounced. The intensity of the Soret band, when ozonated with $15 \mu \mathrm{g} / \mathrm{ml}$ and $55 \mu \mathrm{g} / \mathrm{ml}$ ozone increased compared to the non-ozonated $\mathrm{Hb}$ sample. However, ozonation at $35 \mu \mathrm{g} / \mathrm{ml}$, caused a reduction in the Soret band, below the Soret band seen for the non-ozonated sample. As for the non-diabetic individual and the other diabetic patients, the changes were less pronounced.

\section{UV-VIS absorption spectroscopy}

UV-VIS absorption is caused due to changes in the secondary and tertiary structures of a protein as well as the heme group configuration [31]. UV-VIS absorption of $\mathrm{Hb}$ shows peaks representing the presence of the heme prosthetic group recognized by its heterocyclic porphyrin structure [35]. In UV-VIS absorption spectroscopy, peaks at $222 \mathrm{~nm}$ and about $278 \mathrm{~nm}$ are related to the $\mathrm{n} \rightarrow \pi^{*}$ transition of amidic bonds and aromatic residues including tryptophan, tyrosine and phenylalanine, respectively [36]. UV-VIS spectra of porphyrin rings are formed from their $\pi$ electrons detected through 3 original bands: the B-band at $414 \mathrm{~nm}$ (same as the Soret band in Soret-UV CD) and a pair of Q-bands at the longer wavelengths in the visible region at 542 and $577 \mathrm{~nm}$ [35]. In all $\mathrm{Hb}$ samples analysed in this study, the intensity of $222 \mathrm{~nm}$ and $278 \mathrm{~nm}$ bands remained unchanged, indicating that ozonation did not have a noticeable effect on either the peptide bond or the aromatic residues of the protein (Fig. 6). Having said that, in the diabetic patients $\mathrm{D}$ and $\mathrm{E}$, changes occurred in the shape of the peptide band and it shifted towards larger wavelengths (Fig. 6d, e).

Overall, looking at the UV-VIS spectra, there are not many significant changes in either the $\mathrm{Hb}$ of the nondiabetic individual A or the four diabetic patients in the presence or absence of ozone treatment. However, by closer analysis of the UV-VIS spectra and the Soret and Q-bands in Fig. 7, we find that the diabetic patients D and $E$, similar to the shape changes seen for their peptide bands and their shift, showed some changes and almost doubling in the band intensities, such that the intensity of the bands increased greatly especially in the $\mathrm{Hb}$ samples of patient $\mathrm{D}$ (according to data seen for the wavelength range 360-460). Furthermore, there were no signs of methemoglobin formation as a result of ozonation in $\mathrm{Hb}$ of either the non-diabetic individual $\mathrm{A}$ or the four diabetic patients (according to data seen for the wavelength range 460-660). All Hb samples were in their oxygenated state as identified through the two distinguishable peaks at 542 and $577 \mathrm{~nm}$ (Q-bands).
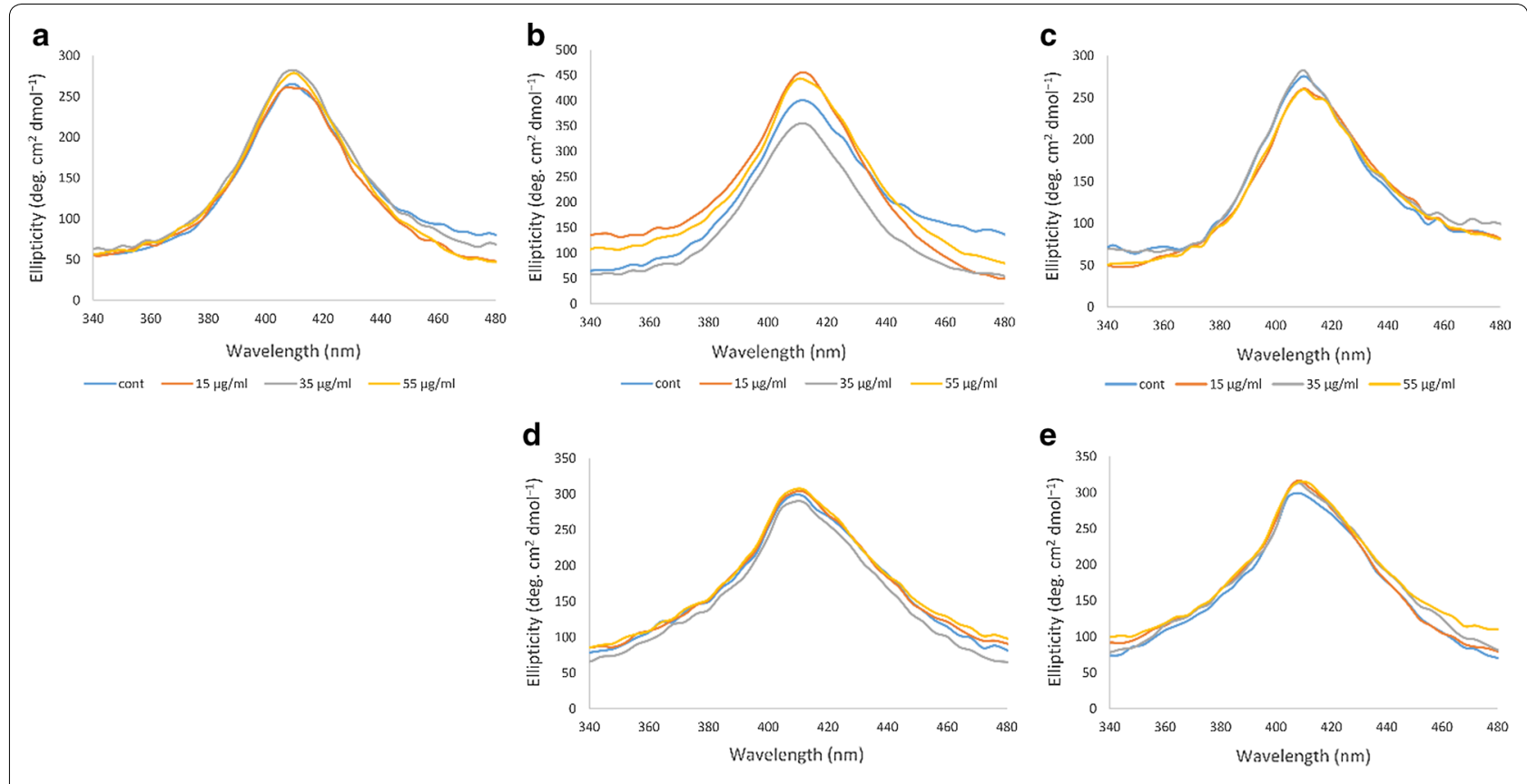

Fig. 5 Soret-UV CD spectral changes of ozonated whole blood oxy-Hb from five human samples. a Soret-UV spectra of oxy-Hb for the non-diabetic individual A. b-e Soret-UV spectra of oxy-Hb for the diabetic patients B to E, respectively 
Mehraban et al. J Transl Med

(2019) 17:227

Page 9 of 15
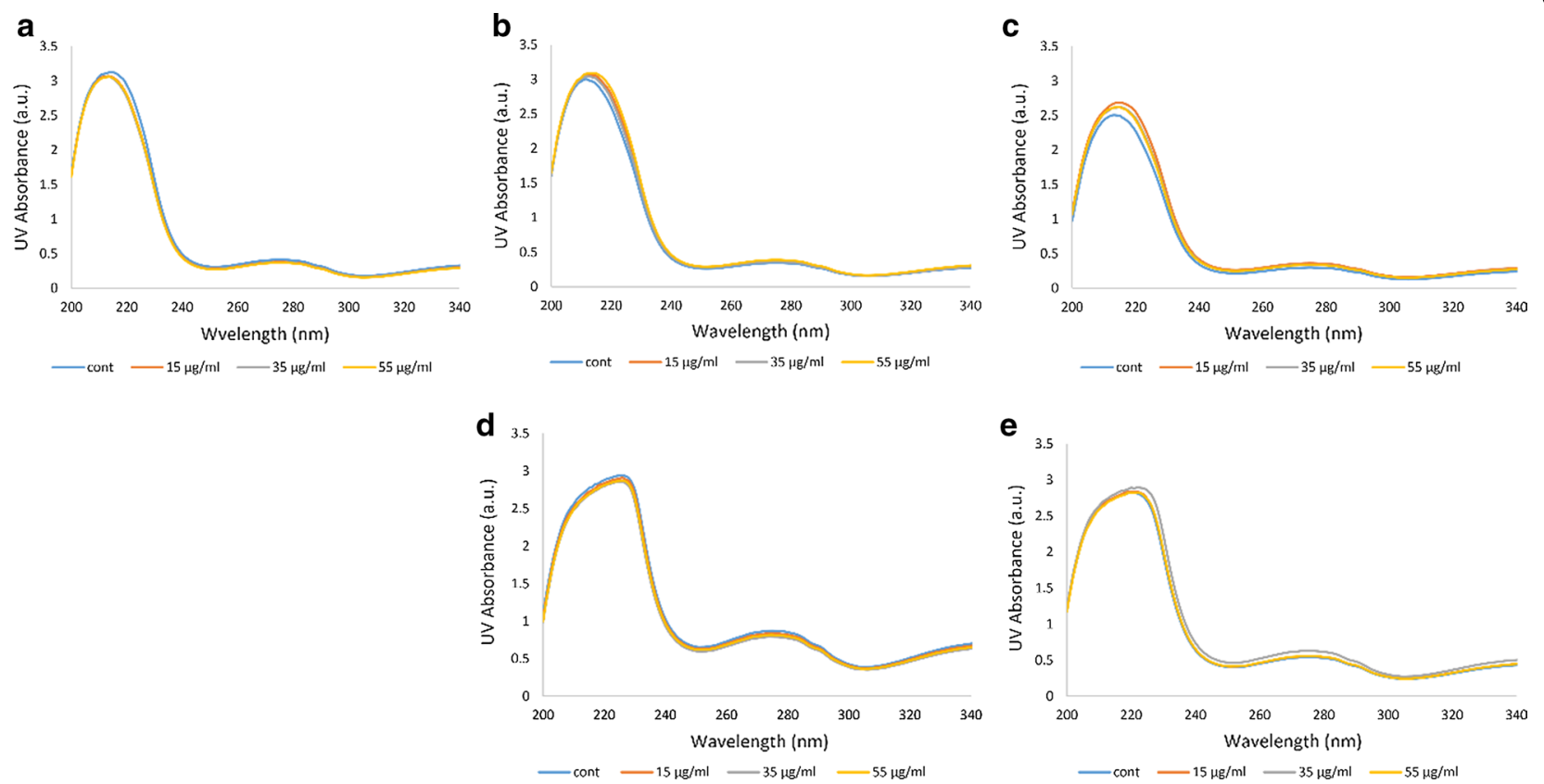

Fig. 6 UV-VIS absorption spectral changes related to the peptide and aromatic residue bands. a UV-VIS spectra of oxy-Hb for the non-diabetic individual A. bye UV-VIS spectra of oxy-Hb for the diabetic patients B to E, respectively. The peaks are related to the $222 \mathrm{~nm}$ peptide band and $278 \mathrm{~nm}$ aromatic residues band
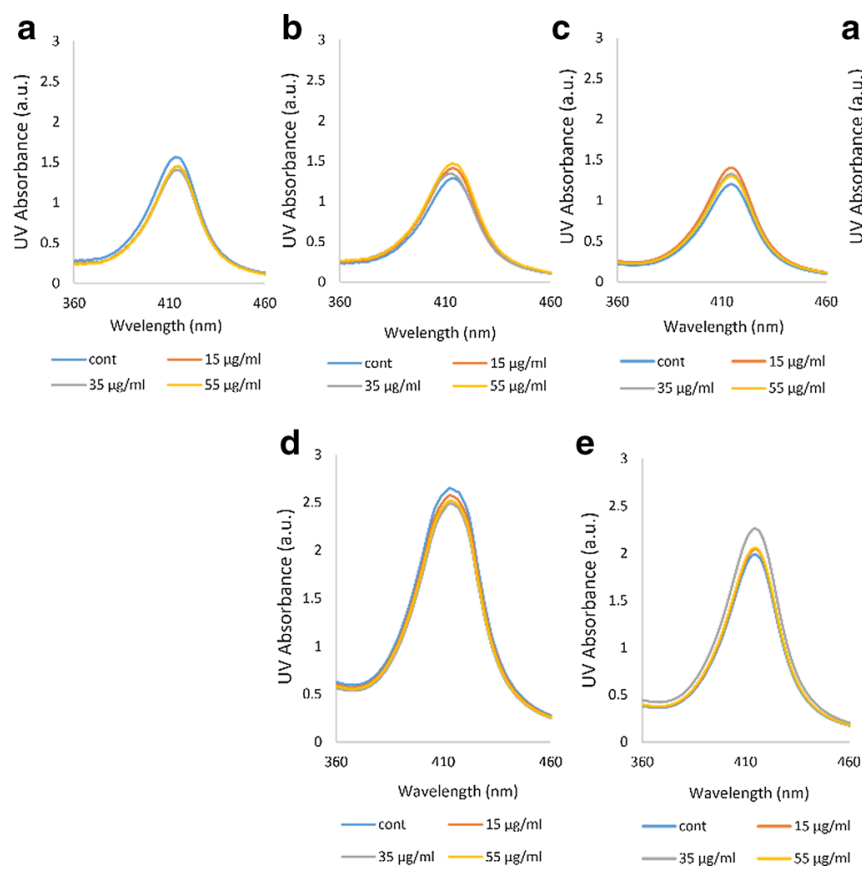
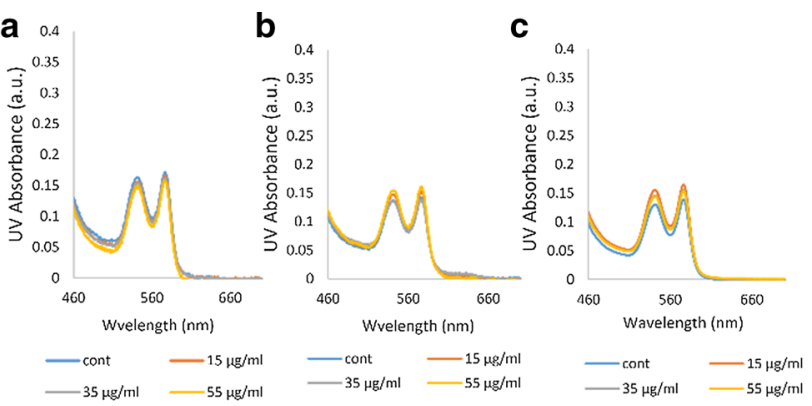

d

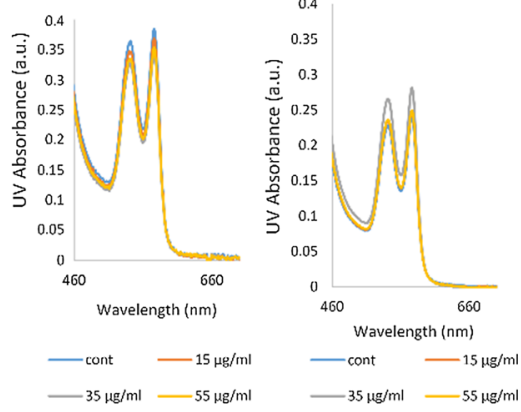

Fig. 7 UV-VIS absorption spectral changes related to B- or Sort and Q-bands. a UV-VIS spectra of oxy-Hb for the non-diabetic individual A. bye UV-VIS spectra of oxy-Hb for the diabetic patients B to E, respectively. Spectral changes related to $414 \mathrm{~nm}$ B- or Sort band is shown on the left and that for 542 and $577 \mathrm{~nm}$ Q-bands shown on the right hand side of the figure 


\section{SDS- and Native-PAGE}

$\mathrm{Hb}$ is a tetrameric macromolecule composed of four polypeptide chains associated via non-covalent bonds with each polypeptide chain carrying a heme prosthetic group [37]. Protein migration using SDS-PAGE strongly depends on the hydrodynamic properties of the protein, shape and level of the surface charge [38]. In general, we find that there are no significant changes in the $\mathrm{Hb}$ monomer and dimer bandwidths in either the nondiabetic individual $\mathrm{A}$ or the four diabetic patients and in $\mathrm{Hb}$ samples exposed to different concentrations of ozone in both cases, in the presence or absence of DTT as a reducing agent (Fig. 8). However, the major differences are in the appearance of a smear and the formation of higher molecular weight bands such as trimers, tetramers and oligomers. In the diabetic patients $\mathrm{B}$ and $\mathrm{C}$ and in the non-diabetic individual $\mathrm{A}, \mathrm{Hb}$ samples (as assessed by SDS-PAGE under both reducing and nonreducing conditions) were found to be less degraded. Furthermore, there were fewer multiple bands or smears seen for $\mathrm{Hb}$ of these individuals related to trimers, tetramers and oligomers (Fig. 8, gels I, II, IV and $\mathrm{V})$. However, in the diabetic patients $\mathrm{D}$ and $\mathrm{E}$, there was evidence of greater $\mathrm{Hb}$ degradation and the presence of multiple higher molecular weight bands and smears, as well as the formation of oligomers showing the instability of $\mathrm{Hb}$ in these patients (Fig. 8, gels III and VI). As in our previous work [26], looking at the SDS-PAGE results under reducing conditions (using DTT), we can see a main thick $\mathrm{Hb}$ band migrated between the 10 and $15 \mathrm{kDa}$ molecular weight marker bands, indicative of the reduced and denatured alpha and beta globins of $\mathrm{Hb}$ with almost similar molecular weights. The next obvious protein band with a lower intensity belongs to a band between the 25 and $35 \mathrm{kDa}$ molecular weight marker bands, indicative of the dimer of $\mathrm{Hb}$. In the presence of DTT, there are additional bands below the $25 \mathrm{kDa}$ marker band and above the $35 \mathrm{kDa}$ marker band, which may be either due to the degradation of $\mathrm{Hb}$ by ROS randomly attacking the carbon methene bonds in the tetrapyrrole rings and creating various pyrrole products that can bind together by covalent bonds, as reported previously [39] or be due to the formation of trimers and tetramers of $\mathrm{Hb}$. These additional bands are hardly seen in $\mathrm{Hb}$ samples of patients $\mathrm{B}$ and $\mathrm{C}$ but more evident in $\mathrm{Hb}$ samples of patients $\mathrm{D}$ and $\mathrm{E}$ and especially in the non-ozonated $\mathrm{Hb}$ sample of patient E (Fig. 8, gel III). In the absence of DTT, however, the

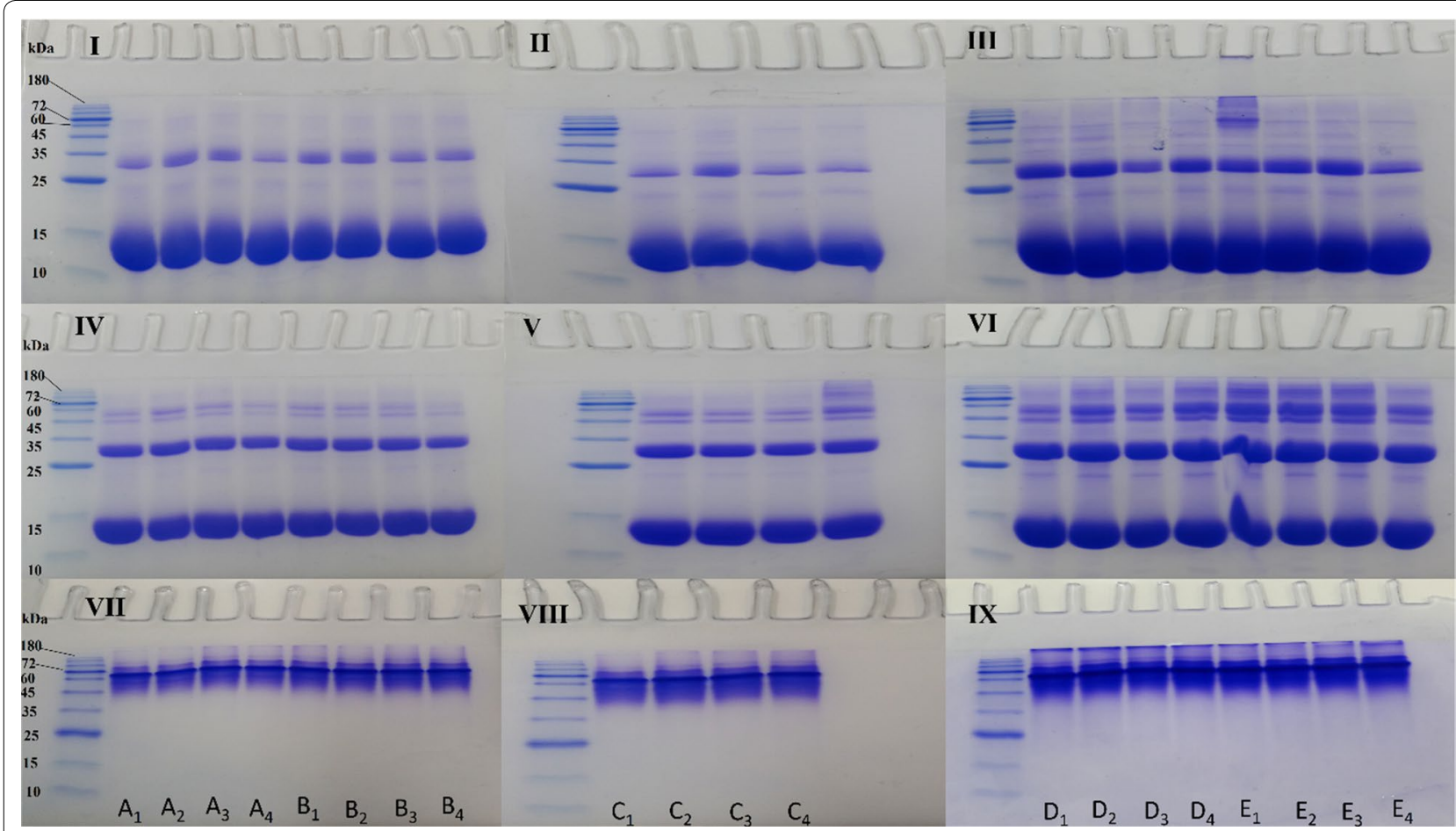

Fig. 8 SDS- and Native-PAGE analyses of ozonated whole blood oxy-Hb from five human samples. Gels I, II and III show Hb samples analysed by SDS-PAGE under reducing conditions (in the presence of DTT). Gels IV, $\mathbf{V}$ and $\mathbf{V I}$, show Hb samples analysed by SDS-PAGE under non-reducing conditions (in the absence of DTT). Gels VII, VIII and IX show Hb samples analysed by Native-PAGE. Samples A-E include oxy-Hb samples of the non-diabetic individual A and diabetic patients B to E, respectively. Samples in all gels: First lane —Protein marker; Samples numbered 1-4_ non-ozonated and ozone treated samples at $15 \mu \mathrm{g} / \mathrm{ml}, 35 \mu \mathrm{g} / \mathrm{ml}$ and $55 \mu \mathrm{g} / \mathrm{ml}$, respectively 
bandwidth of the monomeric $\mathrm{Hb}$ band is reduced and added to the dimer bandwidth, which is due to the presence of disulfide linkages, becoming more apparent under non-reducing conditions. In addition, ozonation appeared to have increased the formation of bands indicative of trimers and tetramers and in some cases oligomers through either covalent di-tyrosine cross-links [40] or through disulfide bonds perhaps via the formation of giant extracellular $\mathrm{Hb}$, as previously reported to exist [38], which is more apparent in the $\mathrm{Hb}$ samples of patients $\mathrm{D}$ and $\mathrm{E}$ but also in $\mathrm{Hb}$ samples of patient $C$ treated with $55 \mu \mathrm{g} / \mathrm{ml}$ ozone (Fig. 8, gels $\mathrm{V}$ and $\mathrm{VI})$. Interestingly, in the case of patient $\mathrm{E}$, ozone at a high concentration of $55 \mu \mathrm{g} / \mathrm{ml}$ had reduced the likelihood of oligomer formation, while this high concentration of ozone resulted in the formation of oligomers in patients $\mathrm{C}$ and $\mathrm{D}$ (Fig. 8, gels $\mathrm{V}$ and VI). In the $\mathrm{Hb}$ samples of the non-diabetic individual $\mathrm{A}$, there was no significant effect caused by exposing $\mathrm{Hb}$ to different ozone concentrations, such that even at $55 \mu \mathrm{g} / \mathrm{ml}$ ozone, a similar state of $\mathrm{Hb}$ was seen compared to the non-ozonated $\mathrm{Hb}$ sample. In $\mathrm{Hb}$ samples of the diabetic patient $B$, ozone at different concentrations had little effect on the likelihood of the formation of oligomers and $55 \mu \mathrm{g} / \mathrm{ml}$ of ozone showed similar or better effects than the control non-ozonated $\mathrm{Hb}$ sample, in preventing oligomer formation.

In $\mathrm{Hb}$ samples of the diabetic patient $\mathrm{C}$ and in the presence of DTT, a pronounced reduction in the intensity of the monomer band and increase in the dimer bandwidth was seen when ozonated at $15 \mu \mathrm{g} / \mathrm{ml}$. Furthermore, in the absence of DTT, ozonation at $55 \mu \mathrm{g} /$ $\mathrm{ml}$ tremendously increased the possibility of oligomer formation. In $\mathrm{Hb}$ samples of the diabetic patient $\mathrm{D}$, ozonation at $35 \mu \mathrm{g} / \mathrm{ml}$ showed to reduce the formation of smears and oligomers compared to the other two ozone concentrations of $15 \mu \mathrm{g} / \mathrm{ml}$ and $55 \mu \mathrm{g} / \mathrm{ml}$. In $\mathrm{Hb}$ samples of the diabetic patient $\mathrm{E}$, the non-ozonated $\mathrm{Hb}$ control sample revealed to have intense bands indicative of tetramer and oligomer formation. Interestingly, ozonation at $55 \mu \mathrm{g} / \mathrm{ml}$, decreased the presence of these bands and hence helped to reduce the formation of these oligomeric species. Native-PAGE for $\mathrm{Hb}$ of the non-diabetic individual and the four diabetic patients showed the tetramer of $\mathrm{Hb}$ as the predominant band near the $60 \mathrm{kDa}$ molecular weight marker band (Fig. 8, gels VII, VIII and IX). Native-PAGE results, in line with the SDS-PAGE results, revealed that the $\mathrm{Hb}$ samples of the diabetic patients $\mathrm{D}$ and $\mathrm{E}$ had more pronounced smear formation and also the existence of oligomers or higher molecular weight species, which as mentioned previously, could be due to the degradation caused by ROS randomly attacking the carbon methene bonds in the tetrapyrrole rings [39] and or the formation of covalent di-tyrosine cross-links [40].

\section{Dynamic light scattering}

DLS results for whole blood oxy-Hb from the non-diabetic individual and the four diabetic patients are given in Table 2 and Fig. 9. In the non-diabetic individual A, ozone concentrations of $15 \mu \mathrm{g} / \mathrm{ml}$ and $55 \mu \mathrm{g} / \mathrm{ml}$ increased the diameter size of the $\mathrm{Hb}$ only slightly, while ozonation at $35 \mu \mathrm{g} / \mathrm{ml}$ had no effect on the $\mathrm{Hb}$ diameter size in the number mode. In the diabetic patient $\mathrm{B}$, the diameter size of the $\mathrm{Hb}$ increased at $35 \mu \mathrm{g} / \mathrm{ml}$ ozone compared to the control non-ozonated $\mathrm{Hb}$ sample of the same patient. The $\mathrm{Hb}$ diameter for this patient at the other two other concentrations of $15 \mu \mathrm{g} / \mathrm{ml}$ and $55 \mu \mathrm{g} / \mathrm{ml}$ ozone were close to the non-ozonated sample. In the diabetic patient $\mathrm{C}$, all three ozone concentrations increased the Hb diameter size, with the greatest increase in diameter size of $\mathrm{Hb}$ detected at $15 \mu \mathrm{g} / \mathrm{ml}$ ozone in the number mode. This is in agreement with the SDS-PAGE results (under reducing conditions) where in gel II of Fig. 8 we observe that at $15 \mu \mathrm{g} / \mathrm{ml}$ of ozone, the probability of $\mathrm{Hb}$ degradation and formation of higher molecular weight species increases, and the intensity of the major band for the monomer reduces while the bandwidth of the dimer increases compared to the other $\mathrm{Hb}$ samples for this patient. Assessment of the same samples under non-reducing conditions (Fig. 8, gel V), shows that the possibility of forming oligomers at $55 \mu \mathrm{g} / \mathrm{ml}$ of ozone is more pronounced, which is supported by the DLS intensity mode values for this sample (refer to Table 2). In the diabetic patient $D$, the diameter size of the $\mathrm{Hb}$ was reduced when ozonated at $35 \mu \mathrm{g} / \mathrm{ml}$ and instead increased when ozonated at $15 \mu \mathrm{g} /$ $\mathrm{ml}$ and $55 \mu \mathrm{g} / \mathrm{ml}$. These results are in agreement with the SDS-PAGE results indicating that the lowest probability of oligomer formation is related to the sample ozonated at $35 \mu \mathrm{g} / \mathrm{ml}$ for patient D (Fig. 8, gels III and VI). Furthermore, in the diabetic patient $\mathrm{E}$, the major reduction in $\mathrm{Hb}$ diameter size was observable at $55 \mu \mathrm{g} / \mathrm{ml}$ ozone, while the diameter size of $\mathrm{Hb}$ ozonated at $15 \mu \mathrm{g} / \mathrm{ml}$ and $35 \mu \mathrm{g} / \mathrm{ml}$ ozone had increased compared to the control non-ozonated $\mathrm{Hb}$ sample. In $\mathrm{Hb}$ samples for this diabetic patient, ozonation at $55 \mu \mathrm{g} / \mathrm{ml}$ had reduced the formation of oligomers in line with SDS-PAGE results (Fig. 8, gel III and VI) and appeared most significant.

\section{Discussions}

Results from our study place major emphasis on personalizing ozone concentration for any individual wanting to undergo autohemotherapy based on a number of analytical techniques. Although the $\mathrm{Hb}$ of the diabetic patients did not show major signs of $\mathrm{Hb}$ degradation as depicted by abnormal reduction in $\mathrm{Hb}$ colour or methemoglobin 
Table 2 DLS diameter values in number and intensity modes as well as percentage intensity of ozonated whole blood oxy-Hb of the non-diabetic individual and four diabetic patients

\begin{tabular}{|c|c|c|c|c|}
\hline Samples & Ozone concentrations & $\begin{array}{l}\text { Diameter (nm) } \\
\text { (number mode) }\end{array}$ & $\begin{array}{l}\text { Diameter (nm) } \\
\text { (intensity mode) }\end{array}$ & $\begin{array}{l}\text { Intensity \% } \\
\text { (intensity mode) }\end{array}$ \\
\hline \multirow[t]{4}{*}{$\begin{array}{l}\text { Oxy-Hb } \\
\text { Non-diabetic individual A }\end{array}$} & Non-ozonated & 5.73 & $\begin{array}{l}6.23 \\
155 \\
567\end{array}$ & $\begin{array}{l}18.1 \\
62.7 \\
16\end{array}$ \\
\hline & $15 \mu \mathrm{g} / \mathrm{ml}$ & 6.10 & $\begin{array}{l}6.60 \\
112 \\
365\end{array}$ & $\begin{array}{l}58.3 \\
13.8 \\
27.9\end{array}$ \\
\hline & $35 \mu \mathrm{g} / \mathrm{ml}$ & 5.73 & $\begin{array}{l}6.71 \\
166 \\
956\end{array}$ & $\begin{array}{l}59.6 \\
25.5 \\
13.4\end{array}$ \\
\hline & $55 \mu \mathrm{g} / \mathrm{ml}$ & 6.07 & $\begin{array}{l}6.60 \\
129 \\
469\end{array}$ & $\begin{array}{l}64.1 \\
18.2 \\
17.6\end{array}$ \\
\hline \multirow[t]{4}{*}{$\begin{array}{l}\text { Oxy-Hb } \\
\text { Diabetic patient B }\end{array}$} & Non-ozonated & 5.98 & $\begin{array}{l}6.54 \\
62.5 \\
262\end{array}$ & $\begin{array}{l}55.2 \\
3 \\
41.8\end{array}$ \\
\hline & $15 \mu \mathrm{g} / \mathrm{ml}$ & 6.17 & $\begin{array}{l}6.54 \\
183\end{array}$ & $\begin{array}{l}41.4 \\
58.6\end{array}$ \\
\hline & $35 \mu \mathrm{g} / \mathrm{ml}$ & 6.66 & $\begin{array}{l}6.75 \\
74.5 \\
480\end{array}$ & $\begin{array}{l}30.4 \\
6.4 \\
63.2\end{array}$ \\
\hline & $55 \mu \mathrm{g} / \mathrm{ml}$ & 6.04 & $\begin{array}{l}6.34 \\
168\end{array}$ & $\begin{array}{l}56.1 \\
43.9\end{array}$ \\
\hline \multirow[t]{4}{*}{$\begin{array}{l}\text { Oxy-Hb } \\
\text { Diabetic patient C }\end{array}$} & Non-ozonated & 7.80 & $\begin{array}{l}26.1 \\
262 \\
4260\end{array}$ & $\begin{array}{l}85.4 \\
12.3 \\
2.4\end{array}$ \\
\hline & $15 \mu \mathrm{g} / \mathrm{ml}$ & 15.3 & $\begin{array}{l}31 \\
271 \\
4470\end{array}$ & $\begin{array}{l}68.1 \\
24.6 \\
7.3\end{array}$ \\
\hline & $35 \mu \mathrm{g} / \mathrm{ml}$ & 10.8 & $\begin{array}{l}25.9 \\
791 \\
3610\end{array}$ & $\begin{array}{l}88.5 \\
6.5 \\
5\end{array}$ \\
\hline & $55 \mu \mathrm{g} / \mathrm{ml}$ & 11.5 & $\begin{array}{l}25 \\
459 \\
4270\end{array}$ & $\begin{array}{l}89.4 \\
5.7 \\
4.9\end{array}$ \\
\hline \multirow[t]{4}{*}{$\begin{array}{l}\text { Oxy-Hb } \\
\text { Diabetic patient D }\end{array}$} & Non-ozonated & 5.8 & $\begin{array}{l}8.83 \\
317 \\
5100\end{array}$ & $\begin{array}{l}52.2 \\
29 \\
18.9\end{array}$ \\
\hline & $15 \mu \mathrm{g} / \mathrm{ml}$ & 5.97 & $\begin{array}{l}7.87 \\
201 \\
3180\end{array}$ & $\begin{array}{l}40.7 \\
17.3 \\
41.9\end{array}$ \\
\hline & $35 \mu \mathrm{g} / \mathrm{ml}$ & 5.30 & $\begin{array}{l}7.34 \\
289 \\
4740\end{array}$ & $\begin{array}{l}30.2 \\
25.6 \\
44.1\end{array}$ \\
\hline & $55 \mu \mathrm{g} / \mathrm{ml}$ & 5.90 & $\begin{array}{l}7.27 \\
172 \\
1340 \\
\text { Fourth peak not calculated }\end{array}$ & $\begin{array}{l}32.2 \\
14.3 \\
41.4 \\
\text { Fourth peak not calculated }\end{array}$ \\
\hline \multirow[t]{4}{*}{$\begin{array}{l}\text { Oxy-Hb } \\
\text { Diabetic patient } \mathrm{E}\end{array}$} & Non-ozonated & 7.04 & $\begin{array}{l}7.22 \\
253\end{array}$ & $\begin{array}{l}44.0 \\
56.0\end{array}$ \\
\hline & $15 \mu \mathrm{g} / \mathrm{ml}$ & 7.53 & $\begin{array}{l}7.93 \\
234\end{array}$ & $\begin{array}{l}48.5 \\
51.5\end{array}$ \\
\hline & $35 \mu \mathrm{g} / \mathrm{ml}$ & 7.87 & $\begin{array}{l}8.06 \\
219\end{array}$ & $\begin{array}{l}45.5 \\
54.5\end{array}$ \\
\hline & $55 \mu \mathrm{g} / \mathrm{ml}$ & 6.41 & $\begin{array}{l}7.11 \\
72.3 \\
341\end{array}$ & $\begin{array}{l}56.4 \\
5.5 \\
38.2\end{array}$ \\
\hline
\end{tabular}




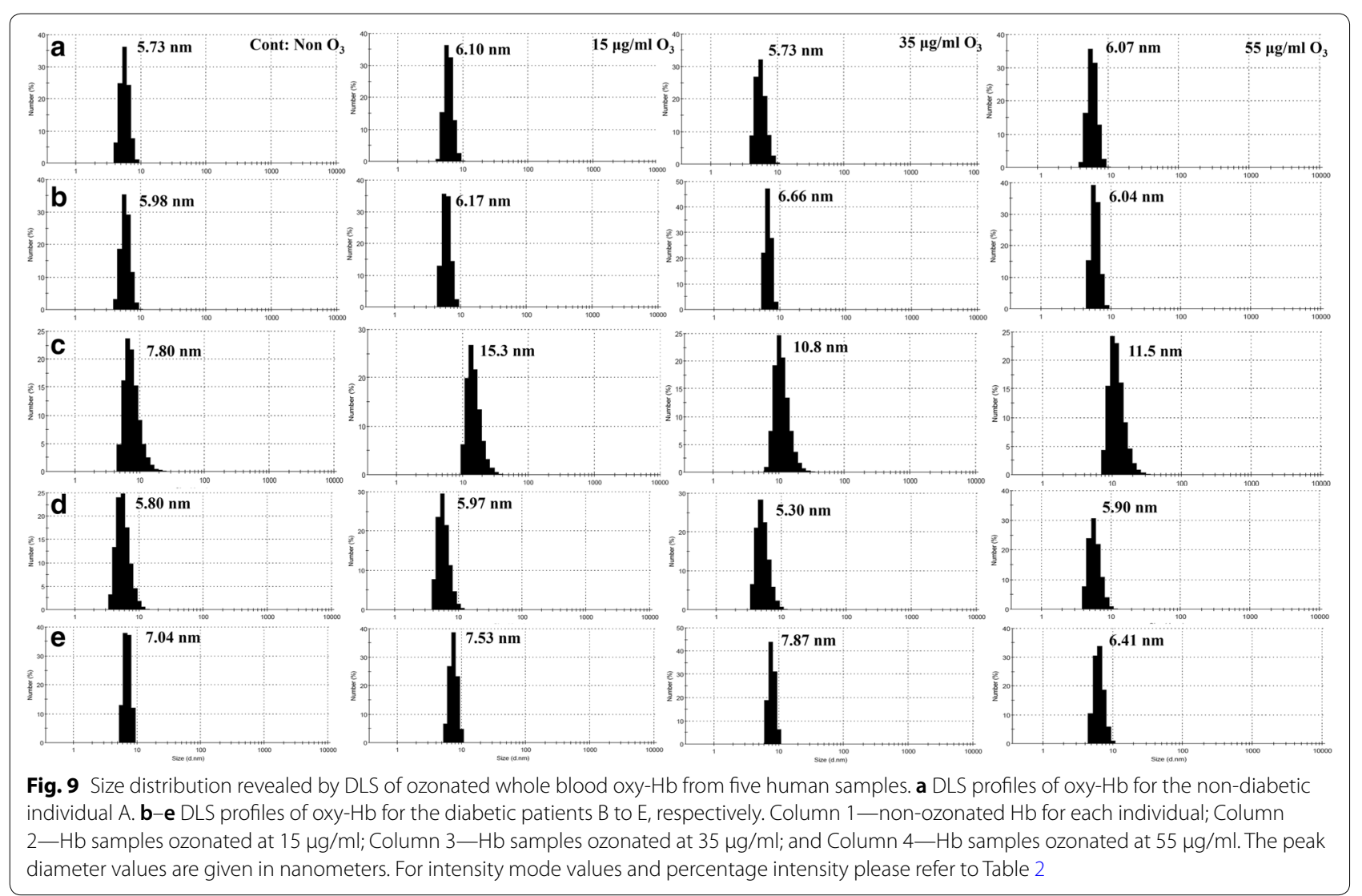

formation, explained by the presence of antioxidants and the method of ozone mixing with whole blood in a syringe, but detailed analysis using a number of techniques and in particular SDS-PAGE and DLS, revealed formation of higher molecular weight species or oligomers of $\mathrm{Hb}$. Our findings showed that ozone is able to affect the $\mathrm{Hb}$ concentration based on absorbance reading at $280 \mathrm{~nm}$ by possibly altering its structure and exposure of aromatic residues. Fluorescence analysis showed that different concentrations of ozone cause changes and polarization in the surrounding environment of the fluorophores (predominantly tryptophans) in the $\mathrm{Hb}$ samples. CD analyses including Far-UV (used to analyze the alpha helix peak intensities for Hb samples), Near-UV (used to detect changes in the aromatic residues) and Soret-UV (used to show changes in the heme group in $\mathrm{Hb}$ samples) were all used to detect secondary and tertiary structural changes of $\mathrm{Hb}$ upon ozonation. Additionally, UV-VIS analysis revealed that no methemoglobin was formed as a result of ozone treatment and all $\mathrm{Hb}$ samples remained in the oxy-state. These techniques were all quite informative, however, SDS-PAGE and DLS highlighted major effects of ozone on $\mathrm{Hb}$ and appeared to be efficient in providing the necessary information for identifying the recommended safe and effective ozone concentration(s) in $\mathrm{O}_{3}$-AHT, as these techniques clearly showed whether or not higher molecular weight species or oligomers are formed. Both these techniques showed the size and state of $\mathrm{Hb}$ in terms of oligomerization.

With regards to SDS-PAGE, in the presence of DTT, the probability of $\mathrm{Hb}$ degradation and the formation of various pyrrole products and trimer via covalent bonds [39], oligomer formation through covalent di-tyrosine cross-links [40] and in the absence of DTT, the formation of disulfide bonds and perhaps the formation of giant extracellular $\mathrm{Hb}$ are observed [38].

In the non-diabetic individual $\mathrm{A}$, analyzed by the three different gels (including reducing and non-reducing SDSPAGE and Native-PAGE), there was no indication for the formation of oligomers and the samples appeared almost the same as that of the control non-ozonated Hb sample. DLS results of the non-diabetic individual A, also showed that the diameter size of ozonated $\mathrm{Hb}$ samples did not change significantly compared to the control. In the diabetic patient $\mathrm{B}$, the probability of forming oligomers was lowest, in the presence of DTT, at the concentration of $15 \mu \mathrm{g} / \mathrm{ml}$ ozone and in the absence of DTT, at $55 \mu \mathrm{g} / \mathrm{ml}$ ozone. DLS results also confirmed this, as the diameter size for $\mathrm{Hb}$ ozonated at 55 and $15 \mu \mathrm{g} / \mathrm{ml}$ ozone were 6.04 and $6.17 \mathrm{~nm}$, respectively, only slightly larger than the 
diameter size of the non-ozonated $\mathrm{Hb}$ at $5.98 \mathrm{~nm}$, but significantly smaller than the diameter size for $\mathrm{Hb}$ ozonated at $35 \mu \mathrm{g} / \mathrm{ml}(6.66 \mathrm{~nm})$.

As for patient $\mathrm{C}$, none of the ozone concentrations seemed appropriate. This is because even though the diameter size for $\mathrm{Hb}$ ozonated at $35 \mu \mathrm{g} / \mathrm{ml}$ ozone for this patient was $10.8 \mathrm{~nm}$, significantly smaller than that measured for the other two ozone concentrations (at $11.5 \mathrm{~nm}$ and $15.3 \mathrm{~nm}$ for $55 \mu \mathrm{g} / \mathrm{ml}$ and $15 \mu \mathrm{g} / \mathrm{ml}$, respectively), the diameter size of the non-ozonated $\mathrm{Hb}$ control sample was much smaller at $7.80 \mathrm{~nm}$. Additionally, SDS-PAGE revealed major oligomerisation at $55 \mu \mathrm{g} / \mathrm{ml}$ ozone for patient $C$. In patient $D$, in either the presence or absence of DTT, the concentration of $35 \mu \mathrm{g} / \mathrm{ml}$ ozone reduced the possibility of forming the undesirable oligomeric $\mathrm{Hb}$ and absorbance at $280 \mathrm{~nm}$ was lower at this ozone concentration compared to $55 \mu \mathrm{g} / \mathrm{ml}$ ozone. DLS also confirmed this as the diameter size for $\mathrm{Hb}$ ozonated at $35 \mu \mathrm{g} / \mathrm{ml}$ ozone was $5.30 \mathrm{~nm}$, smaller than the diameter size of the non-ozonated $\mathrm{Hb}$ at $5.80 \mathrm{~nm}$. In patient $\mathrm{E}$, in gels with DTT and without DTT and measurement at $280 \mathrm{~nm}$ wavelength, the concentration of $55 \mu \mathrm{g} / \mathrm{ml}$ ozone was clearly the most appropriate concentration as it caused the greatest reduction in absorbance reading at $280 \mathrm{~nm}$ and reduced the already existing oligomers in the non-ozonated $\mathrm{Hb}$ sample of this patient. DLS results also supported this as the diameter size for $\mathrm{Hb}$ ozonated at $55 \mu \mathrm{g} / \mathrm{ml}$ ozone was $6.41 \mathrm{~nm}$, significantly smaller than the diameter size of the non-ozonated $\mathrm{Hb}$ at $7.04 \mathrm{~nm}$.

\section{Conclusions}

Based on the results obtained from the techniques used in this study, in particular SDS-PAGE and DLS, it can be concluded that in the non-diabetic individual A, there was no significant difference in the $\mathrm{Hb}$ samples when using different concentrations of ozone and that it would be safe to use all ozone concentrations, even $55 \mu \mathrm{g} / \mathrm{ml}$. For the diabetic patient B, it is better to use either $15 \mu \mathrm{g} /$ $\mathrm{ml}$ or $55 \mu \mathrm{g} / \mathrm{ml}$ ozone. For the diabetic patient $\mathrm{C}$, none of the ozone concentrations is recommended. This is because the overall results and in particular DLS results showed that the diameter size of the ozonated $\mathrm{Hb}$ had increased compared to the non-ozonated $\mathrm{Hb}$. Ozonation is absolutely hazardous for this patient since it caused the formation of oligomeric species. On the other hand, for the diabetic patient D, it is advisable to use $35 \mu \mathrm{g} / \mathrm{ml}$ ozone. For the diabetic patient E, ozonation at $55 \mu \mathrm{g} / \mathrm{ml}$ is highly recommended as it caused a great reduction in the presence of oligomers, which existed prior to ozonation i.e. in the non-ozonated $\mathrm{Hb}$ sample from this patient.

In conclusion, it can be suggested that SDS-PAGE and DLS should be used in order to determine the personalized ozone concentration(s) for a safe and effective autohemotherapy based on blood $\mathrm{Hb}$ analysis. The ozone concentration should be highly personalized for each individual undergoing autohemotherapy and should not be generalized in any way.

\section{Abbreviations \\ $\mathrm{O}_{3}$-AHT: autohemotherapy; CD: circular dichroism; DTT: dithiothreitol; DLS: dynamic light scattering; Hb: hemoglobin; ROS: reactive oxygen species; TAC: total antioxidant capacity.}

\section{Acknowledgements}

We greatly thank Dr. Maryam Fahimifar, from the Wound Centre of Dr. Moshtagh and Dr. Mansoureh Farhadian from the Wound Clinic of Comprehensive Center of Neiayesh Health in Tehran, Iran, for helping arrange and collect blood samples from the five individuals used in this study.

\section{Authors' contributions}

FM: Investigation, formal analysis, methodology, writing of the original draft, arranged for sample collection. AS: Conceptualization, investigation, formal analysis, methodology, funding, project administration, resources, supervision, writing-review. SA: Funding, writing-review. VM: Main contributor of funding, producer and provider of the ozone machine, arranged for sample collection. AAMM: Writing-review. All authors read and approved the final manuscript.

\section{Funding}

Authors contributed to the main costs of the research. We also thank the Iranian National Science Foundation (INSF) for their support.

Availability of data and materials

Data and material (where applicable) will be available upon request.

Ethics approval and consent to participate

Consent was obtained for blood sample collection from the five human subjects in this study (ethics code: IR.UT.SPORT.REC.1397.038).

\section{Consent for publication}

Consent is given for publication.

\section{Competing interests}

The authors declare that they have no competing interests.

\section{Author details}

${ }^{1}$ Institute of Biochemistry and Biophysics, University of Tehran, Tehran, Iran.

${ }^{2}$ Gardina Corporation, Tehran, Iran.

Received: 3 April 2019 Accepted: 5 July 2019

Published online: 16 July 2019

\section{References}

1. Bocci V, Zanardi I, Huijberts MSP, Travagli V. Diabetes and chronic oxidative stress. A perspective based on the possible usefulness of ozone therapy. Diabetes Metab Syndr. 2011;5(1):45-9.

2. Baynes HW. Classification, pathophysiology, diagnosis and management of diabetes mellitus. J Diabetes Metab. 2015;6(5):1-9.

3. Knowler WC, Barrett-Connor E, Fowler SE, Hamman RF, Lachin JM, Walker $E A$, et al. Reduction in the incidence of type 2 diabetes with lifestyle intervention or metformin. N Engl J Med. 2002;346(6):393-403.

4. Marathe $\mathrm{PH}, \mathrm{Gao} \mathrm{HX}$, Close KL. American Diabetes Association standards of medical care in diabetes 2017. J Diabetes. 2017;9(4):320-4.

5. Martinez-Sanchez G, Al-Dalain SM, Menendez S, Re L, Giuliani A, Candelario-Jalil E, et al. Therapeutic efficacy of ozone in patients with diabetic foot. Eur J Pharmacol. 2005;523(1):151-61.

6. Rosen P, Nawroth PP, King G, Moller W, Tritschler HJ, Packer L. The role of oxidative stress in the onset and progression of diabetes and its complications: asummary of a Congress Series sponsored byUNESCO-MCBN, 
the American Diabetes Association and the German Diabetes Society. Diabetes Metab Res Rev. 2001;17(3):189-212.

7. Elvis AM, Ekta JS. Ozone therapy: a clinical review. J Nat Sci Biol Med. 2011;2(1):66.

8. Bocci V, Borrelli E, Travagli V, Zanardi I. The ozone paradox: ozone is a strong oxidant as well as a medical drug. Med Res Rev. 2009;29(4):646-82.

9. Leon OS, Menendez S, Merino N, Castillo R, Sam S, Perez L, et al. Ozone oxidative preconditioning: a protection against cellular damage by free radicals. Mediators Inflamm. 1998:7(4):289-94.

10. Calabrese EJ. Hormesis is central to toxicology, pharmacology and risk assessment. Hum Exp Toxicol. 2010;29(4):249-61.

11. Sagai M, Bocci V. Mechanisms of action involved in ozone therapy: is healing induced via a mild oxidative stress? Med Gas Res. 2011:1(1):29.

12. Smith AJ, Oertle J, Warren D, Prato D. Ozone therapy: a critical physiological and diverse clinical evaluation with regard to immune modulation, anti-infectious properties, anti-cancer potential, and impact on antioxidant enzymes. Open J Mol Integr Physiol. 2015;5(03):37.

13. Bocci V, Aldinucci C, Mosci F, Carraro F, Valacchi G. Ozonation of human blood induces a remarkable upregulation of heme oxygenase-1 and heat stress protein-70. Mediators Inflamm. 2007. https://doi. org/10.1155/2007/26785

14. Candelario-Jalil E, MohammedAl-Dalain S, Fernandez OS, Menendez S, Perez-Davison G, Merino N, et al. Oxidative preconditioning affords protection against carbon tetrachloride-induced glycogen depletion and oxidative stress in rats. J Appl Toxicol. 2001;21(4):297-301.

15. Peralta C, Leon OS, Xaus C, Prats N, Jalil EC, Planell ES, et al. Protective effect of ozone treatment on the injury associated with hepatic ischemia-reperfusion: antioxidant-prooxidant balance. Free Radical Res. 1999;31(3):191-6.

16. Peralta C, Xaus C, Bartrons R, Leon OS, Gelpi E, Rosell-Catafau J. Effect of ozone treatment on reactive oxygen species and adenosine production during hepatic ischemia-reperfusion. Free Radical Res. 2000:33(5):595-605.

17. Bocci V. Is it true that ozone is always toxic? The end of a dogma. Toxicol Appl Pharmacol. 2006;216(3):493-504.

18. Bocci V. The case for oxygen-ozonetherapy. Br J Biomed Sci. 2007;64(1):44-9.

19. Viebahn-Hansler R, Leon Fernandez OS, Fahmy Z. Ozone in medicine: the low-dose ozone concept-guidelines and treatment strategies. Ozone Sci Eng. 2012;34(6):408-24.

20. Bocci V, Zanardi I, Travagli V. Ozone: a new therapeutic agent in vascular diseases. Am J Cardiovasc Drugs. 2011:11(2):73-82.

21. Karnaukhova E, Rutardottir S, Rajabi M, Rosenlof LW, Alayash Al, Akerstrom B. Characterization of heme binding to recombinant a1-microglobulin. Front Physiol. 2014;5:465

22. Pham-Huy LA, He H, Pham-Huy C. Free radicals, antioxidants in disease and health. Int J Biomed Sci. 2008;4(2):89.

23. Rahbani-Nobar ME, Rahimi-Pour A, Rahbani-Nobar M, Adi-Beig F, Mirhashemi SM. Total antioxidant capacity, superoxide dismutase and glutathione peroxidase in diabetic patients. Med J Islam Acad Sci. 1999:12(4):109-14.
24. Serafini M, Villano D, Spera G, Pellegrini N. Redox molecules and cancer prevention: the importance of understanding the role of the antioxidant network. Nutr Cancer. 2006;56(2):232-40.

25. Travagli V, Zanardi I, Bernini P, Nepi S, Tenori L, Bocci V. Effects of ozone blood treatment on the metabolite profile of human blood. Int J Toxicol. 2010;29(2):165-74.

26. Mehraban F, Seyedarabi A, Seraj Z, Ahmadian S, Poursasan N, Rayati $\mathrm{S}$, et al. Molecular insights into the effect of ozone on human hemoglobin in autohemotherapy: highlighting the importance of the presence of blood antioxidants during ozonation. Int J Biol Macromol. 2018;119:1276-85.

27. Travagli V, Zanardi I, Silvietti A, Bocci V. A physicochemical investigation on the effects of ozone on blood. Int J Biol Macromol. 2007:41(5):504-11.

28. Bocci VA, Zanardi I, Travagli V. Ozone acting on human blood yields a hormetic dose-response relationship. J Transl Med. 2011;9(1):66.

29. Bocci V. Ozone A new medical drug. The Netherlands: Springer; 2005.

30. Trachootham D, Lu W, Ogasawara MA, Valle NRD, Huang P. Redox regulation of cell survival. Antioxid Redox Signal. 2008;10(8):1343-74.

31. Munoz G, De Juan A. pH-and time-dependent hemoglobin transitions: a case study for process modelling. Anal Chim Acta. 2007:595(1):198-208.

32. Basu A, Kumar GS. Interaction of toxic azo dyes with heme protein: biophysical insights into the binding aspect of the food additive amaranth with human hemoglobin. J Hazard Mater. 2015;289:204-9.

33. Li D, Zhang T, Ji B. Influences of $\mathrm{pH}$, urea and metal ions on the interaction of sinomenine with Lysozyme by steady state fluorescence spectroscopy. Spectrochim Acta Part A Mol Biomol Spectrosc. 2014;130:440-6.

34. Li R, Nagai Y, Nagai M. Changes of tyrosine and tryptophan residues in human hemoglobin by oxygen binding: near-and far-UV circular dichroism of isolated chains and recombined hemoglobin. J Inorg Biochem. 2000;82(1):93-101.

35. Cataldo F, Gentilini L. On the action of ozone on whole bovine blood. Polym Degrad Stab. 2005;89(3):527-33.

36. Sharma VK, Graham NJD. Oxidation of amino acids, peptides and proteins by ozone: a review. Ozone Sci Eng. 2010;32(2):81-90.

37. Stryer L. Biochemistry, 1995. New York: H Freeman \& Co; 1995.

38. Carvalho FAO, Carvalho JWP, Santiago PS, Tabak M. Further characterization of the subunits of the giant extracellular hemoglobin of Glossoscolex paulistus (HbGp) by SDS-PAGE electrophoresis and MALDI-TOF-MS. Process Biochem. 2011;46(11):2144-51.

39. Nagababu E, Rifkind JM. Heme degradation by reactive oxygen species. Antioxid Redox Signal. 2004;6(6):967-78.

40. Kampf CJ, Liu F, Reinmuth-Selzle K, Berkemeier T, Meusel H, Shiraiwa M, et al. Protein cross-linking and oligomerization through dityrosine formation upon exposure to ozone. Environ Sci Technol. 2015;49(18):10859-66.

\section{Publisher's Note}

Springer Nature remains neutral with regard to jurisdictional claims in published maps and institutional affiliations.

Ready to submit your research? Choose BMC and benefit from:

- fast, convenient online submission

- thorough peer review by experienced researchers in your field

- rapid publication on acceptance

- support for research data, including large and complex data types

- gold Open Access which fosters wider collaboration and increased citations

- maximum visibility for your research: over 100M website views per year

At BMC, research is always in progress.

Learn more biomedcentral.com/submissions 